\title{
The Effect of Social Support from Friends on Deprocrastination among Final Year Student
}

\author{
$1^{\text {st }}$ Madyan $^{1}, 2^{\text {nd }}$ Afriansyah ${ }^{2}, 3^{\text {rd }}$ Anggi Loren ${ }^{3}, 4^{\text {th }}$ Ahdiyat Mahendra $^{4}, 5^{\text {th }}$ Dewi Agustina $^{5}$ \\ \{madyan@uinjambi.ac.id ${ }^{1}$, afriansyah@uinjambi.ac.id ${ }^{2}$, anggicompas5@gmail.com ${ }^{3}$ \\ ahdiyatmahendra@uinjambi.ac.id ${ }^{4}$ dewiagustina801@gmail.com $\left.{ }^{5}\right\}$
}

UIN Sulthan Thaha Saifuddin Jambi ${ }^{1,2,3,4,5}$

\begin{abstract}
The research objective is to examine the question of why final year students in university postpone their final project. This research used a survey method, by using the regression technique. The subjects in this study amounted to 137 students consisting of students in Faculty of Da'wah class 2017. The researcher conclude that the level of social support of friends for the high category is $87.59 \%$ ( 120 students), the medium category is $12 \%$ ( 17 students), based on this it shows that the social support of friends is in the high category, namely $87.59 \%$. The researcher conclude that procrastination for the high category is $64.94 \%$ ( 89 students), the medium category is $35.06 \%$ (48 students), it shows that procrastination is in the high category, which is $64.94 \%$. And the results of the study shows that social support from friends does not affect the level of student procrastination in completing a thesis.
\end{abstract}

Keywords: Social support, procrastination, youth.

\section{Introduction}

Students are an asset to the nation because students are a group of people who study at a university with their respective fields of knowledge. So with the rapid development of society, students who will lead the nation must be ready to face the changes and problems that will occur due to the changes themselves to be able to answer the challenges that will occur[1].

Social support from friends is the process of giving and receiving help from fellow friends according to an attitude of mutual respect. Share responsibilities and provide a helping hand treatment. Social support from friends is also a condition in which the individual will later develop his own decisions, and feel accepted and supported towards his goals[2].

Procrastination according to Ferrari, Johnson, and McCown associated with a tendency to delay the completion of a task and time to do the task. Individuals who procrastinate are always doing alternative activities that replace relevant activities and are often seen as a method of overcoming anxiety due to difficulties in making choices or decisions, or in taking action. Individuals who do procrastinate unconsciously will always cancel what was done until they are trapped in a circle or cycle of procrastination[3].

The results of the initial observations of research at the Da'wah Faculty of UIN STS Jambi regarding the process of making the thesis of 10 people that I observed said that in making the thesis it was very influential from Friends' Social Support on student 
procrastination in writing thesis. of students of the da'wah faculty of 2017 totaling 222 people, from BPI majors 83 students, KPI majors 73 students, JI majors 52 students, and students who have contracted seventh-semester lectures totaling 208 people, data on students who have carried out proposal seminars on seventh-semester students amounted to 35 students [4].

The researcher chose to study the influence of friends' social support on procrastination in completing the thesis because many UIN JAMBI students, especially the Da'wah Faculty, were still relaxing in making theses, and researchers wanted to see the effect of this friend's social support on procrastination in completing theses. Whether the level of procrastination is high, whether the level of procrastination is moderate, low, or has no effect.

\section{Methodology}

The research approach used in this research is survey quantitative research, which is a process of finding the knowledge by using data in the form of numbers as a means of analyzing information about what you want to know. and used to obtain data from certain natural studies. In this study, the Correlation Regression Technique was used to measure the effect between two variables. The measurement between the two variables will result in a decision, namely the existence of Friend's Social Support for procrastination in completing the thesis. If the higher the Social Support of Friends, the lower the level of procrastination, and if the lower the Social Support of Friends, the higher the level of procrastination. The steps in taking the sample are Simple Random Sampling because the sampling of members of the population is carried out randomly without regard to the strata that exist in the population to be sampled.

The method that researchers used to collect research data was a quantitative survey method with a scale as a data collection tool. A scale is a set of questions structured to reveal certain problems through responses to questions/statements[5].

\section{Result and Discussion}

\subsection{Friends' social support}

Sarson, Shearin, et al define social support from friends as the presence, the willingness of caring from people who can be relied upon to appreciate and love us. Gottlieb also explains that peer social support is verbal or non-verbal information, advice, real help, or behavior given by people who are familiar with the subject in a social environment[6].

Social support is a concern for comfort or assistance that a person receives from others, it is obtained by individuals or groups. The social support that is obtained makes a person feel cared for and loved, has self-esteem, and is valued in social networks[7].

Social Support Aspects of Friends. House suggests several forms of social support from friends, namely:

1. Emotional support

Expressed in the form of assistance that provides support to provide warmth and affection, giving attention, trusting individuals, and expressing sympathy. Like when an individual feels lonely or sad, friends always support or comfort the individual.

2. Award Support 
Appreciation support can be given through awards or positive evaluations to individuals, encouragement to move forward and enthusiasm or approval of individual ideas or opinions, and making positive comparisons with others. For example, when individuals need ideas or insights, at that time they have discussions with their friends.

3. Instrumental Support

Direct instrumental support Includes, for example, providing assistance or assisting with doing a job to help with individual tasks.

4. Information Support

Provide information, advice, suggestions, or feedback about what other people in need should do. For example, when individuals need information about scholarships or studies, usually friends who are active in their organizations have more information, and if they have friends who are less actively organized they discuss to get a light on the problem.

5. Social Network Support

Network support is provided by means of making a person's condition to be part of a group that has the same interests and social activities. Social network support is also called friendship support which is a positive social interaction with other people, which allows individuals to spend time with other individuals in a social activity or entertainment[8].

Taylor said that social support effectively reduced levels of psychological distress as well as depression and anxiety. Social support from family and friends is a moderator of stress on adjustment and health. Social support is a social bond that describes the quality of interpersonal relationships. Interpersonal relationships with other people are an aspect to provide emotional satisfaction. Social support makes individuals feel calm, loved, confident and competent.

\subsection{Procrastination}

Procrastination comes from the Latin "pro" which means going forward, preferring, and "castings" which means tomorrow. So from the origin of the word procrastination is preferring to do his job tomorrow. People who do procrastinate are called procrastinators. Procrastination is deliberately delaying an activity that must be done despite knowing that procrastination can have a negative impact[9].

Students think that writing a thesis is a burden that creates pressure. Creating or writing a thesis can cause stress to students. Students choose to do procrastinate to avoid stress. Academic procrastination will hinder students in writing thesis. Students who are depressed due to procrastination will feel anxious, hopeless and blame themselves. Of course, students must get a lot of support from parents, friends, or lecturers to reduce the level of procrastination behavior.

Friend interaction is the beginning of a friendship or friendship in which there is a reciprocal or mutually beneficial relationship. While procrastination is a delay in starting or completing the task at hand, delay in doing the task, the time gap between the plan and actual performance, and doing other activities that are more fun than doing the tasks that must be done. So with the social support of friends, the level of procrastination will be low as figure follow: 


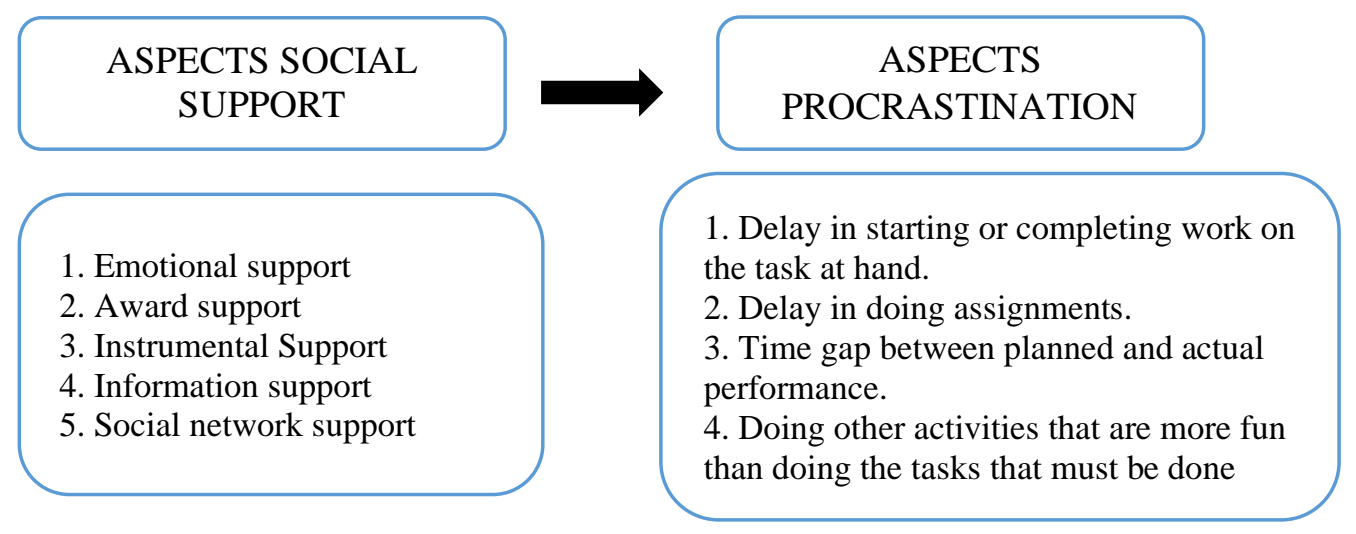

Fig. 1. Social Support and Procrastination Aspect

\subsection{History of the Da'wah Faculty}

The Da'wah Faculty of UIN Sulthan Thaha Saifuddin Jambi was originally one of the departments in the Ushuluddin Faculty (now the Ushuluddin Faculty and Religious Studies), namely the Da'wah Department, which has existed since the inception of IAIN Sulthan Thaha Saifuddin Jambi on September 8, 1967. Located at the Faculty of Ushuluddin and Religious Studies at UIN Sulthan Thaha Saifuddin Jambi, the Department of Da'wah has become a favorite department that attracts prospective da'wah scholars from various regions in Indonesia, especially districts/cities in Jambi Province, even from outside Jambi Province[10].

The da'wah faculty is located at the State Islamic University of Sulthan Thaha Saifuddin Jambi which is located at Jl. Cross Jambi - Muara Bulian KM.16, Simpang Sei Duren, Jambi Outer City, Muaro Jambi, Jambi 36361, Jambi. Precisely behind the Prof. Auditorium Auditorium building. DR.H.M. Chatib Quzwein, MA. The da'wah faculty has three buildings, namely the Ibn Sina building, the M. Iqbal building, and the Dean's building.

The Da'wah Faculty has 4 Study Programs, while the study programs at the Da'wah Faculty of UIN Sulthan Thaha Saifuddin Jambi are:

a. In the Islamic Communication and Broadcasting Study Program (KPI), the graduates are absorbed in addition to being da'wah scientists (teachers, researchers), but also working as preachers in private and government offices. The preacher of various PHBI events, thanksgiving ceremonies, walimah, interpreter of Islamic Religion at the Ministry of Religion and Defense, preachers in the media industry both print and electronic, magazines and books, as well as broadcasting through radio, television, and film.

b. The Islamic Extension Guidance Study Program (BPI) is absorbed by the Ministry of Religion/ KUA/ BP4 as: Teachers, BP/BK Teachers, Supervisors (Religion, Hajj/Umrah, Pre-Marriage, Sakinah Family) and Religious Counselors; Diknas as Teachers, Teacher BP/BK. BKKBN as: Extension agents; ABRI-Police Counselors as Mental Advisors (Bimtal); Correctional Institution as Religious Counselor; Local Government as Career Guidance (Employment); Hospital as Islamic Spiritual Nurse (Warois); Rehabilitation Institution as Therapist, Company as Career Advisor; NGOs as Religious Social Activists; Publisher and Radio as: Writer, Counselor, and Counselor. 
c. Islamic Journalism Study Program (JI), graduates are absorbed as scientists (teachers, researchers, analysts); Practitioners (reporters, journalists, editors, editors, columnists, radio/TV broadcasters, scriptwriters, cameramen, speakers, film/TV producers, radio/TV program producers, and others); Others (diplomat, negotiator/lobbyist, conference organizer, website creator, trainer, instructor, communication specialist, and others).

d. Da'wah Management Study Program (MD), graduates have absorbed apart from being da'wah scientists (teachers, preachers, researchers), also working in ministries/government institutions that are related to the planning and management of ummah development both in terms of guidance, counseling, and Islamic broadcasting (da'wah). 'wah bi ahsani qawl) as well as in terms of da'wah bi ahsani 'amal (social engineering action); specifically for the Ministry of Religion, it can fill the shortage of professionals in planning and managing the development of people's lives and leadership in all directories from the center to the regions; in private institutions are eligible to become executive leaders (managers) of Islamic da'wah and political institutions (all institutions carrying out Islamic da'wah missions); development management assistance, management of Islamic institutions, both government and private, assistant to the Amil Zakat, Infaq and Shadaqah (BAZIS) Agency, Hajj and Umrah Worship Guidance, and Islamic gender empowerment manager.

\section{Conclusion}

The researcher can conclude that the level of social support of friends for the high category is $87.59 \%$ (120 students), the medium category is $12 \%$ (17 students), based on this it shows that the social support of friends is in the high category, namely $87.59 \%$. The researcher can conclude that procrastination for the high category is $64.94 \%$ ( 89 students), the medium category is $35.06 \%$ (48 students), based on this it shows that procrastination is in the high category, which is $64.94 \%$. And the results of the study can be seen from the magnitude of the coefficient of determination of the variables that occur in the procrastination variable in students seen in column R 0.021 or $0.021 \%$ and this shows that social support from friends does not affect the level of student procrastination in completing thesis. We can also see from the theory that according to Young, social support has two forms, namely received social support and perceived social support. Perceived social support is measured by asking the extent to which a person perceives or believes that he is being helped by others. Sarson found that perceived social support was correlated with mental health.

Acknowledgment. Authors thank UIN Sulthan Thaha Saifuddin Jambi for the financial support to present and publish this paper at The First International Conference on Education, Science, Technology, Indonesian, and Islamic Studies (ICESTIIS).

\section{References}

[1] Ilma Surya Istichomarani and Sandra Susan Habibah, "Mewujudkan peran Mahasiswa Sebagai AGENT OF CHANGE, SOCIAL CONTROL, DAN IRON STOCK," 2016. .

[2] D. Monica, "Hubungan Antara Dukungan Teman dan Perilaku Sehat Pada Mahasiswa Universitas Islam Indonesia.," 2018. .

[3] A. Rahmandani, "Pemaafan dan Prokrastinasi Akademik Mahasiswa," J. Psikol. UNDIP, vol. 16, no. 1, p. 16, 2017. 
[4] "Observation."

[5] M. A. Fadhillah, "Kontribusi Kepercayaan Diri Terhadap Hasil Belajar Keterampilan Bermain Bulutangkis Berdasarkan Tingkat Kecemasan."

[6] B. S. Lubis, "Hubungan Antara Dukungan Sosial Teman Sebaya Dengan Prokrastinasi Akademik Pada Mahasiswa Psikologi Dalam Menyelesaikan Skripsi di Universitas Medan Area," in Essay, Medan: Universitas Medan Area, 2018, p. 29.

[7] I. D. G. A. D. and Supriyadi, "Hubungan Kontrol Diri, Beban Kerja dan Dukugan Sosial Teman Terhadap Prokrastinasi Akademik Pada Mahasiswa Universitas Udayana yang Bekerja Part Time," Univrsitas Udayana Paupasli.

[8] N. S. Wahyuni, "Hubungan Dukungan Sosial Teman Dengan Kemampuan Bersosialisasi Pada Siswa SMK Negeri 3 Medan," J. Diverista, vol. 2, no. 2, 2016.

[9] S. Mariyanti, "Prokrastinasi Kebiasaan Menunda Tugas/Pekerjaan." .

[10] Deputy Dean I of the Faculty of Da'wah, "Softfile of History of the Faculty of Da'wah." 